\title{
СУЩНОСТЬ, СТРУКТУРА И ТИПОЛОГИЯ МОДЕЛЕЙ ЭКОНОМИЧЕСКОЙ ДЕЗИНТЕГРАЦИИ
}

\author{
(C) 2021 Фадеева Инна Авенировна \\ кандидат экономических наук, профессор \\ Дипломатическая академия Министерства иностранных дел Российской Федерации, \\ Россия, Москва \\ E-mail: innaf576@mail.ru
}

Целью исследования является расширение теоретико-методологических основ процессов экономической дезинтеграции. Среди задачи исследования: уточнение сущности модели экономической дезинтеграции; анализ структуры элементов модели экономической дезинтеграции; классификация моделей экономической дезинтеграции. В статье проводится анализ некоторых тенденций современности. Приведены сведения, характеризующие снижение темпов интеграционных процессов и возникновение новых дезинтеграционных проявлений в различных регионах мира. Приведено понятие терминов «дезинтеграционные процессы», «дезинтеграционные проявления», «дезинтеграционные тенденции», «модель экономической дезинтеграции». Предложено модель экономической дезинтеграции рассматривать структурно как совокупность элементов: объективные причины и условия экономической дезинтеграции; субъекты экономической дезинтеграции и их цели; институциональные механизмы экономической дезинтеграции; организационные последствия и формы экономической дезинтеграции: реинтеграционные процессы, глубокие преобразования в структуре интеграции, разрыв экономических связей.

Ключевые слова: экономическая дезинтеграция, модель экономической дезинтеграции, структура, сущность, классификация.

Глобальные экономические кризисы, глубинные изменения в региональных и национальных экономиках, стремления государств к обеспечению суверенитета являются причинами, ускоряющими дезинтеграционные процессы. Одним из самых ярких дезинтеграционных процессов современности, выразившийся в своей крайней форме - выходе одного из членов из интеграционного объединения,- безусловно, является выход Великобритании из ЕС. Данному дезинтеграционному процессу предшествовал ряд дезинтеграционных проявлений на территории ЕС.

Выход Великобритании из ЕС нельзя рассматривать как способное иметь аналогов в будущем. ЕС ввиду противоречий в самом договоре об интеграционном объединении, непоследовательной политике наднациональных структур, наличия нерешенных внутренних конфликтов и ряда других причин является весьма неустойчивой структурой с выраженным дезинтеграционным потенциалом. Действительно, с одной стороны, многие страны стремятся к членству в EC (в основном страны с переходной экономикой или развивающиеся страны) и в последние несколько десятилетий данная интеграционная структура только расширялась. Тем не менее, политика экономического «выравнивания» за счет более развитых государств ЕС и многие другие факторы определяют усиление рисков появления новых дезинтеграционных событий в данной интеграционной структуре. Дезинтеграционные риски характерны не только для ЕС, но и для других международных организаций и союзов [1].

Беспрецедентный экономический кризис, вызванный пандемией нового коронавируса также углубляет существующие противоречия в различных интеграционных объединениях и требует научного осмысления. Например, согласно результатам исследования Conflict Barometer в 2017, 2018, 2019 гг. конфликт между Каталонией и официальными властями Испании по пятибалльной шкале оценивался в 3 балла, что соответствует конфликту с применением насилия [2]. Такое значение количественной оценки конфликта выросло впервые за последние годы.

Ускорение процессов дезинтеграции требует научного осмысления существующих мо- 
делей дезинтеграционных процессов. Теорией международной экономической интеграции предложены различные типологии моделей экономической интеграции. Анализ подходов к типологизации моделей экономической интеграции - необходимое условие группировки моделей экономической дезинтеграции.

Достаточно широкая классификационная группировка представлена в исследовании К.М.Багдасаряна, который разделяет интеграционные модели в зависимости от ряда укрупненных и частных признаков:

1. Совокупных условий: территориальные границы интеграции (международная, трансконтинентальная, региональная), экспансивность объединения (внешнее и внутренне развитие), скорость интеграции (низкая, высокая), направленность (закрытый регионализм, открытый регионализм).

2. Институциональных механизмов взаимодействия: институциональное оформление, глубина интеграции, форма взаимодействия, цели и задачи интеграции.

3. Субъекты интеграции: транснациональные корпорации, национальные корпорации, государство [3].

Некоторые из критериев классификации могут использоваться и при анализе моделей дезинтеграционных процессов, например:

- направленность дезинтеграции;

- характер дезинтеграционного процесса;

- скорость дезинтеграционного процесса;

- субъектный состав дезинтеграционного процесса;

- формы дезинтеграционных проявлений.

Важно учитывать, что интеграционный процесс - не всегда является прямым противопоставлением дезинтеграционному. Под дезинтеграционными процессами понимаются инициированные на локальном, национальном или наднациональном уровне процессы трансформации международной (региональной) экономической системы - интеграционной структуры, ведущий к изменению степени и характера взаимосвязей между странами-участницами интеграционной структуры (от частичной до полной трансформации экономических взаимосвязей). Дезинтеграционные процессы находят выражение в формах дезинтеграции, дезинтеграционных тенденциях, дезинтеграционных проявлениях и дезинтеграционных закономерностях.
Под формами дезинтеграционных процессов предлагается понимать конкретные проявления, тенденции и закономерности, способствующие или ведущие к нарушению целостности, ослаблению внутренних связей, распаду интеграционной структуры. Проявления дезинтеграционных процессов - это конкретные выражения ослабления взаимосвязей в рамках интеграционной структуры, которые могут быть охарактеризованы количественно или в качественных характеристиках и свидетельствуют о нарушениях целостности интеграции. Дезинтеграционные тенденции - это устойчивые во времени дезинтеграционные проявления, характеризующие их определенную направленность. Под дезинтеграционной закономерностью будем понимать совокупность дезинтеграционных проявлений и тенденций, выливающихся в их новое качество и позволяющих с высокой степенью вероятности отобразить будущее состояние интеграционной структуры.

Мы придерживаемся широкого подхода к пониманию дезинтеграционных процессов. Дезинтеграционные процессы по своему характеру - явление динамичное, сложное, которое не может сводиться только к крайним формам своего проявления - полному или частичному распаду интеграционной структуры. Отождествление дезинтеграции только распаду интеграционных структур значительно обедняет возможности изучения рассматриваемого сложного явления, хотя в отечественных и зарубежных исследованиях получил распространение узкий подход к пониманию дезинтеграции и дезинтеграционных процессов [4].

А. М.Либман и Б.А. Хейфец выделяют шесть моделей экономической интеграции в зависимости от ведущих субъектов интеграционных процессов и отношений власти: межправительственных договоров, неформальной торговли, доминирующего участника, корпоративного взаимодействия, общего центра, негосударственного права [5].

Д.И.Ушкалова среди наиболее значимых характеристик интеграционного процесса, способных рассматриваться как критерии классификации моделей дезинтеграции выделяет:

- последовательность устранения барьеров для функционирования общего рынка (или последовательность стадий интеграционного процесса);

- содержание инструментов, используемых 
для устранения барьеров;

- стимулы интеграционных процессов, их движущие механизмы;

- цели интеграционных процессов;

- соотношение формальной и неформальной составляющей в интеграционном процессе;

- выбранные участниками механизмы принятия интеграционных решений;

- обязательность выполнения принятых решений;

- возможность разноуровневой и разноскоростной интеграции [6].

Для целей анализа дезинтеграционных процессов из подхода Д.И. Ушкаловой также нельзя использовать все из перечисленных критериев, основываясь лишь на «зеркальном» принципе. Модели экономической дезинтеграции могут быть классифицированы по таким критериям как:

- цели и причины дезинтеграционных проявлений;

- выбранные сторонами механизмы ослабления экономических связей;

- характер ослабления экономических связей и их управляемость.

Существенно меньше внимания в исследованиях уделено моделям экономической дезинтеграции. Т.В.Воронина выделяет четыре дезинтеграционные модели модель встроенной дезинтеграции; дезинтеграция многоуровневых систем; дезинтеграция, протекающая в результате отсутствия страны-ядра; дезинтеграция, протекающая как результат потери силы лидера [7].

В работе А.М.Либмана и Б.А.Хейфеца [8] в зависимости от источника дезинтеграционных процессов («снизу» или «сверху») и скорости протекания дезинтеграционных процессов выделяется четыре модели дезинтеграционных процессов:

1) Конфликтная дезинтеграция, инициированная «сверху» и протекающая с высокой скоростью.

2) Стагнирующая дезинтеграция, также инициированная «сверху» и протекающая с низкой скоростью.

3) Шоковая дезинтеграция, инициированная «снизу» с высокой скоростью.

4) Дивергентная дезинтеграция, протекающая «снизу» с низкой скоростью.

Большая степень исследования и систематизации интеграционных процессов объясняется тем, что работы в данном направлении появились в период ускорения интеграционных процессов в странах Европы и мира. Как показывает анализ количества действующих соглашений о региональных торговых соглашениях за укрупненные периоды [9], в последние годы наблюдается снижение темпов интеграционных процессов в мире, изменение структуры существующих интеграционных объединений, появление качественно новых (в том числе транрегиональных) [10]. Все это неизбежно сопровождается дезинтеграционными процессами. Из 43 региональных торговых соглашений, заключенных в период с 17 января 2020 года по 10 февраля 2021 года, 31 соглашение пришлось на Великобританию - то есть имело реинтеграционный характер как результат выхода страны из ЕС и необходимости формирования новой сети международных экономических связей.

Для уточнения сущности понятия «модель экономической дезинтеграции», обратимся к некоторым трактовкам понятия «модель». Под «моделью» могут понимать:

- абстрактное представление реальности, выраженное в какой-либо форме (графической, математической, символической и др.) [11];

- физическое, математическое или иное логическое представление системы, сущности, явления или процесса [12];

- представление одной или нескольких концепций, которые могут быть реализованы в физическом пространстве [13];

- упрощенное представление системы в определенный момент времени и пространства, используемое для содействия понимания реальной системы [14];

- абстракций системы, используемая для понимания и интерпретации ключевых аспектов, представляющих интерес для этой системы [15].

Под интеграционной моделью К.М.Багдасарян предлагает понимать общее представление субъектов интеграции о системе отношений, способствующее формированию тесных взаимосвязей для реализации их интересов [16]. В структуру интеграционной модели указанный автор включает элементы: субъекты интеграции, институциональные механизмы взаимодействия и совокупные условия дезинтеграции [16].

Исходя из приведенных определений понятий «модель» и «интеграционная модель», можно сделать предварительные выводы относи- 
тельно сущности дезинтеграционной модели:

- дезинтеграционная модель не может рассматриваться только как описание процесса «отзеркаливающего» интеграционные процессы;

- в отличие от интеграционных процессов, дезинтеграционные процессы могут проявлять себя в не институционализированных формах.

Под моделью экономической дезинтеграции предлагается понимать сложившийся объективно и под влиянием субъектов дезинтеграционных процессов, ход таких процессов, содержание совокупности дезинтеграционных проявлений и дезинтеграционных тенденций, образующих в своей совокупности дезинтеграционные процессы, ведущий к ослаблению, глубокой трансформации или разрыву экономических связей между участниками интеграции.

Модель экономической дезинтеграции структурно может быть представлена в виде элементов:

- объективные причины и условия экономической дезинтеграции;

- субъекты экономической дезинтеграции и их цели;

- институциональные механизмы экономической дезинтеграции;

- организационные последствия и формы экономической дезинтеграции: реинтеграционные процессы, глубокие преобразования в структуре интеграции, разрыв экономических связей.

Полагаем дополнить модели дезинтеграции на основе следующих критериев:

1. Степень прогнозируемого ослабления интеграционного объединения, в том числе это модели дезинтеграции:

- модель неполной, частичной дезинтеграции, предполагающей временное ослабление взаимосвязей между участниками интеграционного объединения;

- модель полной дезинтеграции, ведущая к распаду или самоликвидации интеграционного объединения.

2. Источник противоречий, ставший пусковым механизмом дезинтеграции:

- модель, протекающая под влиянием внутренних противоречий в интеграционном объединении;

- модель дезинтеграции, «запущенная» как результат внешнего влияния на интеграционное объединение.

Таким образом, предложенное определение модели экономической дезинтеграции, структуры данного процесса и их разновидностей расширяет теорию международной экономической интеграции. Предложенные модели могут быть использованы в ходе анализа современных дезинтеграционных процессов.

\section{Библиографический список}

1. Фадеева И. А. Дезинтеграционные проявления в ШОС и их влияние на экономическое развитие государствчленов интеграции // Экономика и предпринимательство. 2019. № 10 (111). С. 212-215.; Фадеева И. А. Оценка влияния дезинтеграционных проявлений в БРИКС на экономику группировки // Азимут научных исследований: экономика и управление. 2020. Т. 9. № 2 (31). С. 347-349.

2. Conflict Barometer. URL: https://hiik.de/conflict-barometer/current-version/?lang=en (дата обращения: 24.01.2021).

3. Багдасарян К. М. Анализ модели экономической интеграции // Журнал экономической теории. 2019. Т. 16. № 3. С. 352-361.

4. Воронина Т.В.Интеграция и дезинтеграция как проявление внутренних противоречий интеграционной системы // Terra Economicus. 2013. Т. 11. № 1-2. С. 119-123; Vollaard H.A (2009). Theory of European disintegration.URL: http://www.jhubc.it/ecpr-riga/virtualpaperroom/017. pdf (дата обращения 20.02.2021).

5. Либман А. М., Хейфец Б. А. Модели региональной интеграции. М.: Экономика, 2011. 333 с.

6. Ушкалова Д. И. Модели экономической интеграции и их типология // Вестник Института экономики Российской академии наук. 2016. № 3. С. 158-170.

7. Воронина Т.В.Международная экономическая интеграция: императивы, противоречия, тенденции развития: дис. ... д-ра экон. наук. Ростов-на-Дону, 2013. с. 121.

8. Либман А.М., Хейфец Б. А. Модели экономической дезинтеграции. Интеграция и дезинтеграция // Евразийская экономическая интеграция. № 2 (11), 2010., С. 4-18.

9. Regional trade agreements. World Trade Organization. URL: https://www.wto.org/english/tratop_e/region_e/ region_e.htm (дата обращения: 19.01.2021).

10. Хейфец Б. А. Трансрегиональное переформатирование глобального экономического пространства. Вызовы для России. М.: Институт экономики РАН, 2016. 86 с. 
11. Глоссарий по информационному обществу / под общ. ред. Ю.Е. Хохлова. М.: Институт развития информационного общества, 2009. 160 с.

12. Modeling and Simulation (M\&S) Glossary. Department of Defense. URL: https:/www.acqnotes.com/Attachments/ DoD\%20M\&S\%20Glossary\%201\%200ct\%2011.pdf (дата обращения: 19.01.2021).

13. Friedenthal S., Moore A., Steiner R. A Practical Guide to Systems Modeling Language. 2012. Publisher: Morgan Kaufmann. 640 p.

14. Bellinger G. Modeling \& Simulation: An Introduction. Systems Thinking. URL: https://www.systems-thinking.org/ modsim/modsim.htm (дата обращения: 19.01.2021).

15. Dori D. Object-Process Methodology: A Holistic Systems Paradigm. Publisher: Springer-Verlag Berlin Heidelberg, $2002.455 \mathrm{p}$.

16. Багдасарян К. М. Анализ модели экономической интеграции // Журнал экономической теории. 2019. Т. 16. № 3. C. 352-361. 